\title{
Spatial patterns of multidrug-resistant tuberculosis: correlation with sociodemographic variables and type of notification
}

\author{
Padrões espaciais da tuberculose multirresistente: correlação com variáveis sociodemográficas e tipo de notificação
}

Estándares espaciales de la tuberculosis multirresistente: correlación con variables sociodemográficas y tipo de notificación

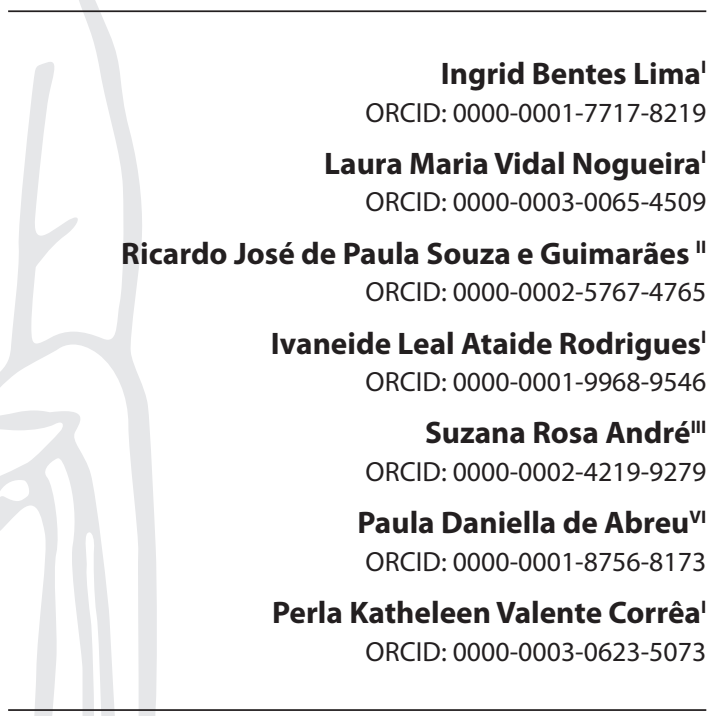

'Universidade do Estado do Pará. Belém, Pará, Brazil. "Instituto Evandro Chagas. Ananindeua, Pará, Brazil. II'Universidade Federal do Rio de Janeiro. Rio de Janeiro, Rio de Janeiro, Brazil. v'Universidade de São Paulo. Ribeirão Preto, São Paulo, Brazil.

How to cite this article: Lima IB, Nogueira LMV, Guimarães RJPS, Rodrigues ILA André SR, Abreu PD, et al. Spatial patterns of multidrug-resistant tuberculosis: correlation with sociodemographic variables and type of notification. Rev Bras Enferm. 2020;73(Suppl 5):e20190845 doi: http://dx.doi.org/10.1590/0034-7167-2019-0845

Corresponding author: Laura Maria Vidal Nogueira E-mail: lauramavidal@gmail.com

EDITOR IN CHIEF: Antonio José De Almeida Filho ASSOCIATE EDITOR: Hugo Fernandes

Submission: 11-29-2019

Approval: 06-10-2020

\section{ABSTRACT}

Objective: Correlate the cases of multidrug-resistant tuberculosis and its spatial patterns with the type of notification and sociodemographic variables. Method: Ecological study carried out in the municipality of Belém, with 77 cases of multidrug-resistant tuberculosis registered in the Special Treatment Information System for Tuberculosis, between 2012 and 2016. For analysis, the data was debugged followed by geo-referencing in ArcGis 10.3 and Terra View 4.2.2. To relate the cases with the type of notification, the BioEstat 5.4 software was used, with a significance level of 95\%. Results: Of the total, 40 (52\%) were new cases; 27 (35\%), relapses; and ten (13\%) were re-enrolled after leaving. Multidrug-resistant tuberculosis was randomly distributed and related to income, household, territorial cluster and water supply. There was a concentration of cases in two administrative districts, corresponding to $28.5 \%$ and $27.3 \%$ of the total, with a median Sociodemographic Index. Conclusion: Behavior of multidrug-resistant tuberculosis influenced by sociodemographic indicators.

Descriptors: Multidrug-Resistant Tuberculosis; Spatial Analysis; Geographic Information Systems; Epidemiology; Public Health.

\section{RESUMO}

Objetivo: Correlacionar os casos de tuberculose multirresistente e seus padrões espaciais com o tipo de notificação e variáveis sociodemográficas. Método: Estudo ecológico realizado no município de Belém, com 77 casos de tuberculose multirresistente registrados no Sistema de Informação de Tratamentos Especiais da Tuberculose, entre 2012 e 2016. Para análise, foi feita depuração dos dados seguida do georreferenciamento nos programas ArcGis 10.3 e Terra View 4.2.2. Para relacionar os casos com o tipo de notificação, utilizou-se o software BioEstat 5.4, com nível de significância de 95\%. Resultados: Do total, 40 (52\%) eram casos novos; 27 (35\%), recidivas; e 10 (13\%) eram reingressos após abandono. A tuberculose multirresistente apresentou distribuição aleatória e relação com renda, aglomerado domiciliar, territorial e abastecimento de água. Houve concentração de casos em dois distritos administrativos, correspondentes a 28,5\% e 27,3\% do total, com Índice Sociodemográfico mediano. Conclusão: Foi constatado comportamento da tuberculose multirresistente influenciado pelos indicadores sociodemográficos.

Descritores: Tuberculose Resistente a Múltiplos Medicamentos; Análise Espacial; Sistemas de Informação Geográfica; Epidemiologia; Saúde Pública.

\section{RESUMEN}

Objetivo: Correlacionar los casos de tuberculosis multirresistente y sus estándares espaciales con el tipo de notificación y variables sociodemográficas. Método: Estudio ecológico realizado en el municipio de Belém, con 77 casos de tuberculosis multirresistente registrados en el Sistema de Información de Tratamientos Especiales de la Tuberculosis, entre 2012 y 2016 . Para análisis, ha sido realizada depuración de los datos seguida de la georreferenciación en los programas ArcGis 10.3 y Terra View 4.2.2. Para relacionar los casos con el tipo de notificación, se utilizó el software BioEstat 5.4, con nivel de significación de 95\%. Resultados: Del total, $40(52 \%)$ eran casos nuevos; $27(35 \%)$, recidivas; y $10(13 \%)$ eran reingresos después del abandono. La tuberculosis multirresistente presentó distribución aleatoria y relación con la renta, aglomerado domiciliar, territorial y abastecimiento de agua. Hubo concentración de casos en dos distritos administrativos, correspondientes a $28,5 \%$ y $27,3 \%$ del total, con Índice Sociodemográfico mediano. Conclusión: Ha sido constatado comportamiento de la tuberculosis multirresistente influenciado por los indicadores sociodemográficos. Descriptores: Tuberculosis Resistente a Múltiplos Medicamentos; Análisis Espacial; Sistemas de Información Geográfica; Epidemiología; Salud Pública. 


\section{INTRODUCTION}

Although treatment methods and techniques have evolved over the years, tuberculosis (TB) remains highlighted as an infectious disease that affects a large part of the world population and that, with the addition of an expressive number of cases of multidrugresistant tuberculosis (MDR-TB), it turns this disease into a global public health problem. The severity of TB has increased in recent decades due to its association with the human immunodeficiency virus (HIV), with multidrug resistance and the greater involvement of people in vulnerable situations. It is a disease also associated, in the social imagination, with stigma, fear and prejudice, factors that impact the control of transmissibility ${ }^{(1-2)}$.

The ability of TB-causing strains to acquire resistance is mainly due to the misuse of drugs, treatment abandonment and mutations. People with multidrug-resistant tuberculosis whose treatment is compromised are subject to drug poisoning processes, in addition to increased financial expenses. Treatment abandonment in drug-resistant TB cases presents the following main risk factors: re-entry after abandonment and/or being a drug user. And for death: reentry after abandonment, bankruptcy (case of TB with positive culture in the fifth month or after, during treatment), poly-resistance and extensive resistance ${ }^{(3)}$.

For 2018, the World Health Organization (WHO) estimated about half a million (between 417,000 and 556,000 ) of new cases of rifampicin-resistant TB (RR TB), with 78\% MDR-TB( ${ }^{(4)}$. In Brazil, in 2017, the incidence rate of MDR-TB and RR TB was 1.2 cases / 100 thousand inhabitants, with an estimate of new cases for the country of 2,000 records of these forms of TB resistance ${ }^{(5)}$.

The reduction in the number of MDR-TB cases is part of the TB control goals proposed by the National Plan for the End of Tuberculosis as a Public Health Problem, representing a public health challenge $\mathrm{e}^{(6)}$. The provision of incentives for social protection, associated with Directly Observed Treatment (DOT), enhances adherence to treatment, especially for people in situations of social vulnerability. However, the multi-causal profile of TB, the result of the social determination of the health-disease process, requires an effective social protection social construction, which is in line with effective proposals to combat vulnerabilities. In order to face TB, one must consider the importance of implementing health policies focused on vulnerable populations in Primary Health Care (PHC), in the reference counter-reference process and in the role of nurses in comprehensive care ${ }^{(7-9)}$.

TB has a strong association with the social inequities of human groups who live in a situation of social exclusion and live in territorial spaces that add greater poverty ${ }^{(8-9)}$. The city of Belém has heterogeneous aspects of the population's living conditions, given the presence of extensive poor areas in which health services do not function satisfactorily, being among the 181 priority Brazilian cities for TB control ${ }^{(10)}$.

The use of technologies to identify the spatial patterns of MDR-TB cases enables greater accuracy and reliability to indicate the spatial location of these cases and relate to the potentializing variables for the occurrence of the phenomenon. In this sense, geoprocessing allows the systematization of data related to the distribution of MDR-TB, with the offer of results to support the implementation of the planning of disease control actions ${ }^{(11-12)}$.
This study sought to answer the following question: What is the correlation of multidrug-resistant tuberculosis cases and their spatial patterns with the type of notification and sociodemographic variables?

\section{OBJECTIVE}

Correlate the cases of multidrug-resistant tuberculosis and its spatial patterns with the type of notification and sociodemographic variables.

\section{METHOD}

\section{Ethical aspects}

This study complied with what was established by Resolution $\mathrm{NHC} / \mathrm{MH}$ No. 466/12, which provides for research involving human beings, being approved by the Research Ethics Committee and access to the database was done by signing the Authorization for Accessing the Database Term(AADBT) by the State Department of Public Health of Pará.

\section{Study design and study site}

This is an epidemiological study, of the ecological type, developed in the municipality of Belém-PA, which has 71 neighborhoods, grouped into eight Administrative Districts for health management purposes, being: Belém Administrative District (DABEL), Bengui Administrative District (DABEN), Entroncamento Administrative District (DAENT), Guamá Administrative District (DAGUA), Icoaraci Administrative District (DAICO), Mosqueiro Administrative District (DAMOS), Outeiro Administrative District (DAOUT) and Sacramenta Administrative District (DASAC).

\section{Population, sample; inclusion and exclusion criteria}

The study population consisted of 77 cases of MDR-TB reported on the TB SITE by the State Department of Public Health of Pará (SESPA), referring to the period from 2012 to 2016. All cases of MDR-TB from people living in the city of Belém with full addresses obtained from the compulsory notification form were included. Two cases that had the address filled in incompletely were excluded.

\section{Study protocol}

The first stage of the study took place from obtaining secondary epidemiological data referring to cases of MDR-TB in TB-SITE, a public and restricted database, composed of the following variables: year of notification, age, sex, education, address and type of notification or type of entry into the system. The type of notification or type of entry corresponds to the classification of the patient's entry into the system: new cases (had never treated TB before or had done it for up to 30 days), relapse (falling ill again after healing) and re-entry after abandonment (when treatment was interrupted for more than 30 days) ${ }^{(13)}$.

In the second stage, the data was debugged using the Microsoft Office Excel ${ }^{\circledR} 2010$ program, with the organization of the 
variables to eliminate possible redundancy and obtain a more consistent and complete database. The third stage consisted of obtaining the digital meshes referring to the cartographic base of the municipality of Belém, available on the website of the Brazilian Institute of Geography and Statistics (IBGE); and the use of geographic coordinates of latitude and longitude for georeferencing patients with MDR-TB based on their addresses. The fourth stage took place from the acquisition of population data with the number of the population living in Belém, obtained from the 2010 Census database, made available by IBGE.

\section{Data analysis}

Descriptive analysis was carried out with measures of dispersion, frequency distribution (mean, fashion and median) and epidemiological indicators. Pearson's chi-square non-parametric statistical test was used to estimate the factors associated with the cases, in addition to the Anderson-Darling normality test. The $95 \%$ significance level was adopted, and the processing was done using the BioEstat 5.4 program. The data was grouped and analyzed according to the administrative districts of Belém and organized in tables, graphs and thematic maps.

The geographic coordinates (latitude and longitude) were obtained using the Freegeocoding and Google Maps tools, as well as the database of the Development and Administration Company of the Metropolitan Area of Belém (CODEM) for the creation of the georeferenced database (GDB). GDB gave rise to two files: (1) file of georeferenced points of MRD-TB cases; and (2) polygon file of the neighborhoods, which was derived from the census sectors of the 2010 IBGE Census.

The socio-demographic variables of the census sectors were used: income up to two minimum wages (income); five or more people per household (people); form of water supply not connected to the network or well (water); form of sewage not connected to the network or septic tank (sewer); and information on the presence of subnormal agglomerations at IBGE to create the Sociodemographic Index [(income + people + water + sewage + subnormal) / 5]. The following classification was considered for the Sociodemographic Index (Sdi): Low Sdi (0-0.25); Average Sdi (0.26-0.5); High Sdi (0.51-0.75); and Very High Sdi (0.76-1). GDBs (points and neighborhoods) were imported into ArcGIS software (https://www.arcgis.com), version 10.4, for the construction of the map of location, distribution, choropleth and risk of MDR-TB cases.

The Kernel Density Estimator (KDE) was used in the TerraView software (http://www.obt.inpe.br/OBT/assuntos/projetos/terralibterraview), version 4.2.2, with the parameters: quadratic function, density calculation and adaptive radius. KDE analyzed the number of MDR-TB cases per area and the incidence rate of MDR-TB per 100 thousand inhabitants, expressing the results through a set of colors, namely: the Low Risk category was associated with the color green; the Medium Risk category, yellow in color; the High Risk category, in orange; and the Very High Risk category, in red. The incidence rate of MDR-TB was calculated using the number of MDR-TB cases in each census sector in the 2010 IBGE Census, divided by the population in the census sector.

Pearson's correlation between the cases and the incidence rate of MDR-TB was performed with Sdi and its variables (income, people, water, sewage, subnormal), using software R (https:// www.r-project.org/).

\section{RESULTS}

Among the 77 cases studied, the types of entry, according to the notification, were identified as follows: 40 (52\%) new cases, $27(35 \%)$ relapses and ten (13\%) re-entry after abandonment (Table 1).

According to Table 1, MDR-TB cases in the municipality of Belém are more concentrated in DASAC neighborhoods, with 23 cases; DAGUA, with 21 cases; and DABEN, with 15 cases. In DASAC, a higher proportion of new cases was identified, with 13 $(32.5 \%)$, and the cases of recurrence were equally distributed in DASAC and DAGUA, with 7 (25.9\%) in each district. Re-entry after abandonment was predominant in DABEN, with 4 (40\%) cases; followed by DASAC, with 3 (30\%) cases.

Tabela 1 - Distribuição dos casos de tuberculose multirresistente, segundo o tipo de notificação e o distrito administrativo de origem do paciente, Belém, Pará, Brasil, 2012-2016

\begin{tabular}{|c|c|c|c|c|c|c|c|}
\hline \multicolumn{8}{|c|}{ Tipo de Notificação } \\
\hline \multirow[t]{2}{*}{ Variável } & \multicolumn{2}{|c|}{$\begin{array}{c}\text { Caso novo } \\
(\mathrm{n}=\mathbf{4 0 )}\end{array}$} & \multicolumn{2}{|c|}{$\begin{array}{c}\text { Recidiva } \\
(n=27)\end{array}$} & \multicolumn{2}{|c|}{$\begin{array}{c}\text { Reingresso } \\
\text { após abandono } \\
(\mathrm{n}=10)\end{array}$} & \multirow[t]{2}{*}{$\begin{array}{l}\text { Valor } \\
\text { de } p^{(1)}\end{array}$} \\
\hline & $\mathbf{n}$ & $\%$ & $\mathbf{n}$ & $\%$ & $\mathbf{n}$ & $\%$ & \\
\hline \multicolumn{8}{|l|}{ Distrito } \\
\hline DASAC & 13 & 32,5 & 7 & 25,9 & 3 & 30,0 & \multirow{8}{*}{0,8583} \\
\hline DAGUA & 10 & 25,0 & 7 & 25,9 & 4 & 40,0 & \\
\hline DABEN & 9 & 22,5 & 5 & 18,5 & 1 & 10,0 & \\
\hline DAENT & 4 & 10,0 & 3 & 11,1 & 2 & 20,0 & \\
\hline DABEL & 2 & 5,0 & 2 & 7,4 & - & - & \\
\hline DAICO & 1 & 2,5 & 2 & 7,4 & - & - & \\
\hline DAMOS & 1 & 2,5 & - & - & - & - & \\
\hline DAOUT & - & - & 1 & 3,7 & - & - & \\
\hline
\end{tabular}

Fonte: SITE-TB / SESPA / PA (2017).

Nota: (1) Teste qui-quadrado de Pearson para correlação $(p<0,05)$; $H_{1}$ : Existe correlação significativa entre as frequências $(p<0,05)$.

It was identified that the monthly average of cases was 1 ( $\mu=$ $1.28 ; \sigma= \pm 1.09$ ), ratified by the median, with $50 \%$ of the months recording at least one case. The variance indicated a homogeneous series without high variability in the frequency of cases over the months. $t$ was possible to identify a higher concentration in the initial phase of the series, characterizing abnormal distribution according to the Anderson-Darling normality test $(p<0.05)$, indicating, therefore, that the distribution is of the leptocurtic and positive asymmetric type ( $\mathrm{X}>0$ and $\mathrm{As}>0$ ).

The descriptive profile analysis, in Table 2 , showed that the types of entry "new case" and "reentry after abandonment" were predominant in the age group 36 to 45 years old, with ten (25\%) and five $(50 \%)$ cases, respectively. In the "relapse" group, eight (29.6\%) patients were aged between 26 and 35 years, and these frequencies were not correlated with the type of notification. There was predominance among younger people in the DAGUA district (5 / 62.5\%), while in DASAC, the illness was more expressive among young adults and adults: age between 26 and 35 years (6 / 31.6\%); 36 and 45 years old ( 7 / 31.8\%); and 46 and 55 years old $(7 / 46.7 \%)$. There was no significant correlation ( $p>0.05$ ) between the frequencies of MDR-TB cases with the age group in the different districts of Belém. 
Regarding gender, likewise, there was no significant trend with the type of notification, with the male gender being the majority in the three groups: 25 (62.5\%) new cases, $18(66.7 \%)$ relapses and $7(7 \%)$ reentry after abandonment (Table 2$)$. At DASAC, ten (37\%) cases were female and $13(26 \%)$ male. At DAGUA, ten (37\%) were female and 11 (22\%) were male; and in DABEN, five (18.5\%) were female and ten (20\%) were male. These differences do not show a significant relationship between the distribution of MDR-TB cases in the districts and the patient's gender ( $p>0.05$ ).

Regarding education, it was found that complete secondary education was more frequent among the types of notification: eight (20\%) new cases, eight (29.6\%) relapses and three (30\%) re-entry after dropping out. None of the variables showed to be correlated with the type of notification of cases ( $p>0.05$ ). The highest frequency occurred in the DASAC district, namely: $6(46.2 \%)$ patients with incomplete education between the 5 th and 8th grades of elementary school; and seven (36.8\%) patients completed high school. There was no significant correlation ( $p>$ 0.05 ) between the frequencies of MDR-TB cases with schooling in different districts (Table 2).

In Figure 1, it is possible to see the spatial distribution of MDRTB cases (Figure $1 \mathrm{~b}$ ) according to the administrative districts (Figure 1a) and the region's Sdi (Figure 1c). There was a higher occurrence of cases in central regions of the municipality, but MDR-TB is identified in other geographical areas of the capital of Pará, although to a lesser extent. In relation to Sdi, DAICO, DABEN and DAMOS had the highest rates - and are districts furthest from the central area. Figures $1 b$ and $1 a$ show that DABEL is a district with few cases and low Sdi, while DASAC and DAGUA stand out with many cases and average Sdi.

Figure $2(A, B, C)$ refers to the distribution of MDR-TB cases in the geographical space according to the type of notification. It is noted that the new cases, recurrences and re-entry after abandonment, respectively, presented the highest distribution densities in DASAC and DAGUA (A); in DABEN, DAENT and DASAC (B); at DASAC, DABEN
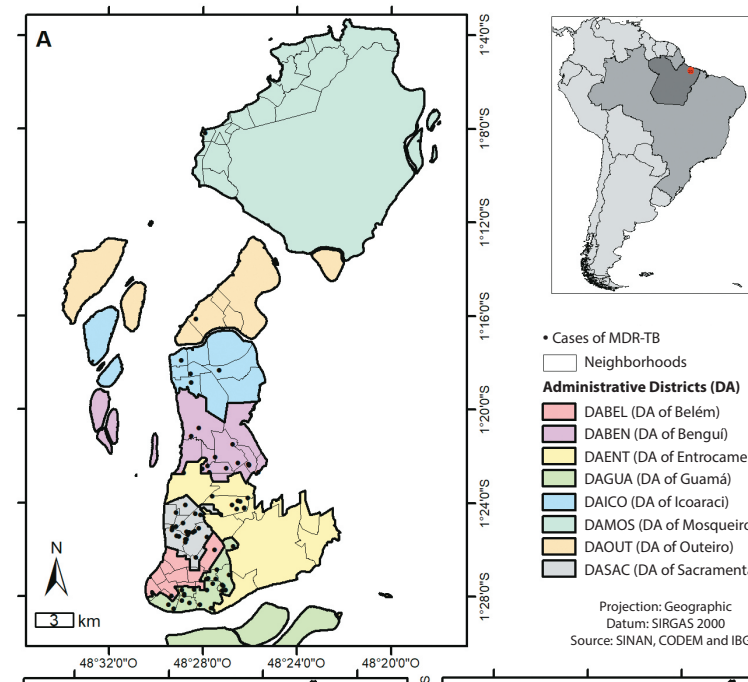

Cases of MDR-TB Neighboric Administrative Districts (DA) DABEL (DA of Belém) DABEN (DA of Bengui) DAENT (DA of Entrocamento) DAGUA (DA of Guamá) DAMOS (DA of Mosqueiro) DAOUT (DA of Outeiro) DASAC (DA of Sacramenta) Projection: Geographic Datum: SIRGAS 2000

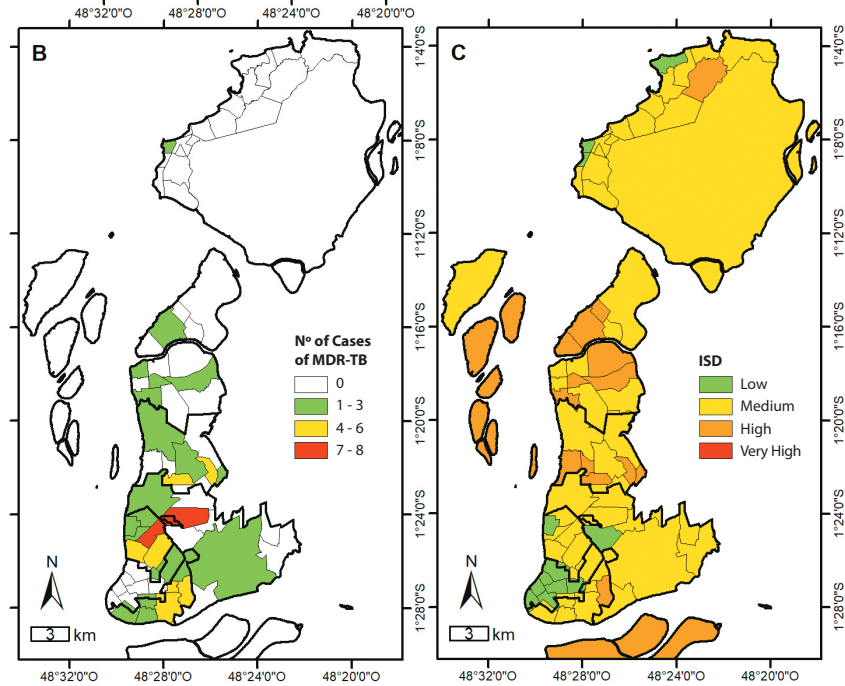

Figure 1 - Administrative Health Districts (A); Number of cases of multidrugresistant tuberculosis (B) and Classes of Sociodemographic Index (C), Belém, Pará, Brazil, 2012-2016

Table 2 - Distribution of new cases of multidrug-resistant tuberculosis, according to the type of entry and the sociodemographic profile, Belém, Pará, Brazil, 2012-2016

\begin{tabular}{|c|c|c|c|c|c|c|c|}
\hline \multirow{3}{*}{ Variable } & \multicolumn{6}{|c|}{ Type of entry } & \multirow{3}{*}{$p$ value $^{(1)}$} \\
\hline & \multicolumn{2}{|c|}{$\begin{array}{c}\text { New case } \\
(n=40)\end{array}$} & \multicolumn{2}{|c|}{$\begin{array}{l}\text { Relapse } \\
(n=27)\end{array}$} & \multicolumn{2}{|c|}{$\begin{array}{l}\text { Re-entry after abandonment } \\
\qquad(\mathrm{n}=10)\end{array}$} & \\
\hline & $\mathbf{n}$ & $\%$ & $\mathbf{n}$ & $\%$ & $\mathbf{n}$ & $\%$ & \\
\hline \multicolumn{8}{|l|}{ Age group } \\
\hline $16-25$ & 5 & 12.5 & 3 & 11.1 & - & - & \\
\hline $26-35$ & 8 & 20.0 & 8 & 29.6 & 3 & 30.0 & \\
\hline $36-45$ & 10 & 25.0 & 7 & 25.9 & 5 & 50.0 & \\
\hline $46-55$ & 9 & 22.5 & 4 & 14.8 & 2 & 20.0 & 0.5600 \\
\hline $56-65$ & 5 & 12.5 & 3 & 11.1 & - & - & \\
\hline 66-75 & 3 & 7.5 & 2 & 7.4 & - & - & \\
\hline \multicolumn{8}{|l|}{ Sex } \\
\hline Female & 15 & 37.5 & 9 & 33.3 & 3 & 30.0 & 08805 \\
\hline Male & 25 & 62.5 & 18 & 66.7 & 7 & 70.0 & 0.8805 \\
\hline \multicolumn{8}{|l|}{ Education } \\
\hline Illiterate & - & - & 1 & 3.7 & - & - & \\
\hline 1st to 4th incomplete grades of elementary school & 5 & 12.5 & 2 & 7.4 & 2 & 20.0 & \\
\hline Complete 4th grade of elementary school & 3 & 7.5 & 2 & 7.4 & 1 & 10.0 & \\
\hline 5th to 8th incomplete grade elementary school & 8 & 20.0 & 3 & 11.1 & 2 & 20.0 & \\
\hline Complete elementary school & - & - & 1 & 3.7 & - & - & \\
\hline Incomplete high school & 7 & 17.5 & 3 & 11.1 & - & - & 0.8562 \\
\hline Complete high school & 8 & 20.0 & 8 & 29.6 & 3 & 30.0 & \\
\hline Incomplete higher education & 1 & 2.5 & 1 & 3.7 & - & - & \\
\hline Complete higher education & 2 & 5.0 & 1 & 3.7 & - & - & \\
\hline lgnored & 6 & 15.0 & 5 & 18.5 & 2 & 20.0 & \\
\hline
\end{tabular}

Source: TB SITE / SESMA / PA (2017).

(1) Pearson's chi-square test for correlation ( $p<0.05)$; $H_{i}$ : There is a significant correlation between frequencies $(p<0.05)$. 
and DAGUA (C). And when the analysis is done using the incidence rates $(E, D, F)$ standardized by district, the highest densities are observed in DASAC for new cases (D); in DAICO, DABEN, DAENT, DASAC, DABEL and DAGUA for cases of recurrence (E); and DASAC, DABEL and DAGUA for cases of re-entry after abandonment (F).

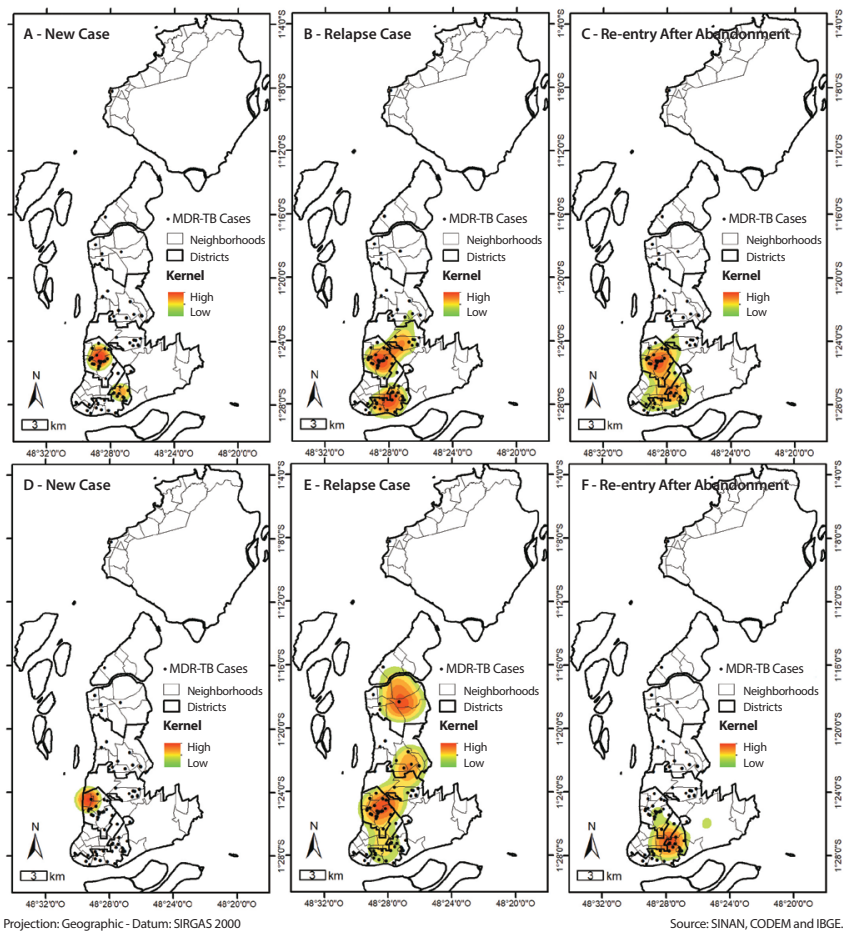

Figure 2 - Application of Kernel Density Estimator by the number of cases of multidrug-resistant tuberculosis $(A, B, C)$ and by the incidence rate $(D, E$, $\mathrm{F})$, respectively, in the concentration of new case, recurrence and re-entry after abandonment, Belém, Pará, Brazil, 2012-2016

The average annual incidence rate of MDR-TB in Belém, during the study period, was 1.1 cases per 100 thousand inhabitants, with higher rates in DASAC, corresponding to 8.5 / 100 thousand inhabitants. This was the district that showed the highest density in new cases (D) and in recurrences (E), as well as low density in re-entry after abandonment (F).

Table 3 presents the result of the correlation test between the cases and the incidence rate of MDR-TB with Sdi and its variables (income, people, water, sewage, subnormal). It became evident that there is a correlation between MDR-TB and Sdi in the variables income, people and subnormal, that is, MDR-TB in the municipality of Belém is related to people who have an income of up to two minimum wages, residing in houses with five or more people, located in subnormal agglomerates (slum or stilt regions). The other variables studied were not significant.

\section{DISCUSSION}

Through the descriptive analysis of the study, it was possible to verify the proportion of cases of MDR-TB and socioeconomic factors. The profile of the cases studied shows a predominance of males, possibly due to the tendency to spread the disease twice as much in men as in women, as well as the lack of self-care being greater among men, in addition to their greater exposure to risk factors ${ }^{(14-17)}$.

According to the study's findings, there was a greater involvement of economically active adults, which may be related to the lifestyle of this population, which does not have a regular meal schedule, who drinks alcohol and, thus, does not continue the Directly Observed treatment (DOT). uch a situation can have a negative impact on the evolution of treatment and on the family economy, due to the consequent unemployment, reduction of hours worked and difficulty to perform paid activities, resulting in income impairment, essentially when it comes to cases of MDR-TB in which treatment is different from standard, with higher cost and time to take anti-TB drugs (14-15,18-19). $^{\text {. }}$

The low educational level identified confirms previous findings and has been associated with non-adherence to specific treatment for TB, due to the possible difficulty presented by the patient to understand the details involving the treatment and control of $\mathrm{TB}^{(20-21)}$. The interruption of the therapeutic regimen hinders the success of the treatment and contributes to the occurrence of MDR-TB, both in the patient himself and in people without a history of illness ${ }^{(14)}$.

In this sense, the expressive number of new cases notified in the period draws attention because they are patients who had not previously had contact with anti-TB drugs, configuring primary resistance. These cases appear concentrated in districts whose social and demographic characteristics are of higher population density and greater poverty ${ }^{(22)}$. Such findings were found in other studies in which TB is related to poor indicators, such as: low household income; low HDI; low per capita income; low life expectancy at birth; and high unemployment rates. All of this strengthens the thesis that TB is related to social inequality ${ }^{(18,23)}$.

The high number of MDR-TB among people who had never previously treated TB is a cause for concern and suggests thinking about flaws in drug-sensitive TB control, with inadequate treatments, leading to therapeutic failure and contributing to the spread of resistant strains among people who have never been previously treated ${ }^{(24)}$. In this context, the high dropout rate that has been identified in the capital of Pará may be affecting primary MDR-TB, since the WHO target for the dropout rate of treatment is $<5 \%$ of cases, but, in the last three years, this rate was above the recommended ${ }^{(7-8)}$.

Table 3 - Pearson's Correlation Test between cases and the incidence rate of multidrug-resistant tuberculosis with Sociodemographic Index and its variables (income, people, water, sewage, subnormal), Belém, Pará, Brazil, 2012-2016

\begin{tabular}{llcccccc}
\hline & & Sdi & Income & People & Water & Sewage & Subnormal \\
\hline \multirow{2}{*}{ Cases } & Pearson & 0.0741 & 0.0828 & 0.0827 & -0.0274 & 0.0020 & 0.0876 \\
\multirow{3}{*}{ Rate } & $p$ value & 0.0070 & 0.0026 & 0.0026 & 0.3197 & 0.9419 & 0.0014 \\
& Pearson & 0.0697 & 0.0769 & 0.0834 & -0.0206 & -0.0045 & 0.0851 \\
& $p$ value & 0.0113 & 0.0051 & 0.0024 & 0.4542 & 0.8693 & 0.0019 \\
\hline
\end{tabular}


The abandonment of treatment is doubly harmful, and may result in MDR-TB in the patient who interrupted the therapeutic regimen, as well as, once multi-resistant, infecting people who have never been sick with TB, with strains already resistant to the drugs. In India, the country with the largest number of multidrug-resistant patients in the world, catastrophic expenses are generated for the private sector, referring to the need for financial support from the public sector for patients undergoing MDR-TB treatment ${ }^{(25)}$.

In this study, $13 \%$ of the cases reported in the period had previously abandoned TB treatment, because of possible failures in the service, and this corroborates the findings in a study carried out in reference hospitals in Ethiopia, which showed poor knowledge and practice of health professionals in the prevention and control of MDR-TB ${ }^{(26)}$. Another determinant factor for bacterial resistance is the unsuccessful treatments that allow the patient to return in the condition of relapses - in this study, corresponding to $35 \%$ of the total notified in the period. Relapse may result from non-compliance with therapeutic rigor or exposure to a new source of contagion after healing; and is 2.7 times more likely to manifest resistance ${ }^{(22)}$.

In addition, there is evidence that municipalities with cases of MDR-TB have less primary care coverage and adherence to DOT, confirming the need for greater attention by health professionals, in the monitoring and control of patients, since DOT is a fundamental strategy for achieving cure, as it promotes adequate intake of anti-TB drugs, when accompanied by trained professionals ${ }^{(23)}$.

DOT is seen as a challenge to reduce MDR-TB, as operational factors and the geopolitical context are barriers to the implementation of this treatment modality. It is known that managers must promote the adherence and decentralization of DOT, essentially nursing, which has a prominent role in the implementation of therapy ${ }^{(27-28)}$. Therefore, measures aimed at specific care become necessary, including the co-responsibility of the actors involved and the strengthening of the bond between professional and person undergoing treatment for TB in order to combat and control TB more effectively ${ }^{(27)}$.

In addition to the personal and institutional factors that trigger multi-resistance, some socioeconomic and environmental conditions also influence the worsening of MDR-TB. This is because TB is closely related to the population's living conditions, being one of the main causes of morbidity and mortality in developing countries, which exhibit strong social inequality, which reflects on the health of individuals, especially those most vulnerable ${ }^{(29)}$.

Regarding sociodemographic variables, the analysis of correlation with cases and rates shows how MDR-TB is directly related to inequality and social inequities ${ }^{(30)}$. Among the characteristics of the municipality of Belém, we highlight the presence of socially and economically deprived areas, which do not have adequate health services, which suffer from periodic flooding, without sanitation and without access to treated water. In addition, it has a high population density, great social heterogeneity, which may justify the random distribution of MDR-TB in the municipality ${ }^{(10)}$.

In this sense, the association of Sdi with cases of MDR-TB is also demonstrated in other studies ${ }^{(31)}$, because the gathering of people facilitates the transmission of the bacillus. In DASAC, low-income population predominates, living in houses without necessary ventilation and excessive humidity, justifying the average Sdi and the possible high number of cases. Likewise, the districts DAGUA AND DAICO, also located in peripheral areas, have a large concentration of people, with low purchasing power and the presence of irregularly arranged dwellings in the territory, classifying it as a subnormal area ${ }^{(32)}$. Localities whose homes are poor, and lack basic sanitation, are prone to poorly functioning health services. The absence of minimum conditions for a dignified life - such as low income, absence of drinking water, deficient sanitation, environmental disorder and human settlement - configures social exclusion, making it a potential geographical space for the illness of TB and, consequently, MDR-TB ${ }^{(8-9,33)}$.

The application of the KDE allowed us to visualize that the cases of MDR-TB studied are located in geographically close districts, characterized as territories with greater poverty and violence, far from the urban center of the city, where people with less education reside. A previous study identified that the people most affected by TB have low income, low education level and high level of poverty ${ }^{(18)}$.

The clusters of more intense points in the DASAC district can be explained by the fact that the analysis of the kernel density is based on the count of points per $\mathrm{km}^{2}$ in influential circulation areas, weighted by the distance of each of the locations of interest, without considering the population of areas ${ }^{(34-35)}$. It was at DASAC that the highest incidence of MDR-TB was identified, a region of the city with medium socio-demographic indicators, typically characterized as an area around the city. It is a highly populated territory, with $18.41 \%$ of the population of the municipality, with monthly income below the minimum wage ${ }^{(36)}$. These data show that the incidence of MDR-TB is related to sociodemographic factors, which therefore play an important role in the impact of TB on the social environment.

\section{Study limitations}

As a limitation, the use of secondary databases was identified, since health information systems should be analyzed with caution because they are records made in the service routine, therefore, subject to underreporting and incompleteness of data.

\section{Contributions to the area of Nursing, Health or Public Policies}

The study advanced as to the location of people with MDR$T B$, explaining its correlation with social inequities, highlighted here in the sociodemographic indexes. It is observed that, even with all the accumulated knowledge, TB is still a concern and has presented itself with more complicated forms for treatment and control, such as MDR-TB. Thus, it is hoped that the results of this research can assist nurses and other health professionals to implement health surveillance measures aimed at achieving the goals of the National Plan for the End of Tuberculosis as a Public Health Problem.

\section{CONCLUSION}

MDR-TB was configured as an issue directly related to the socioeconomic variables of the study: low income, five or more people per household, irregular water supply and subnormal agglomerates. Therefore, professional assistants and managers 
have a great challenge in formulating strategies aimed at controlling MDR-TB, especially for more socially excluded population groups, and must offer quality care with welcoming, counseling, referral to specialized services and ensuring access to a network articulated and effective approach that ensures comprehensive care for TB and MDR-TB cases.

It was observed that the spatial distribution of cases allowed the identification of areas with a higher concentration of MDR-TB, which should be valued by the health authorities of epidemiological surveillance, for the implementation of measures that promptly diagnose these cases and promote treatment with follow-up until cure. In addition, TB cases should be observed within the municipality, monitoring them to avoid treatment interruption and consequent evolution to MDR-TB.

\section{FUNDING}

This study received financial support through the granting of a research grant from the Amazon Foundation to Support Studies and Research - Edital 007/2016 - FAPESPA.

\section{REFERENCES}

1. Arbex MA, Siqueira HR, Ambrósio LD, Migliori GB. The challenge of managing extensively drug-resistant tuberculosis at a referral hospital in the state of São Paulo, Brazil: a report of three cases. J Bras Pneumol [Internet]. 2015[cited 2018 Jul 15];41(6):554-559. Available from: http:// dx.doi.org/10.1590/s1806-37562015000000299

2. Gama KNG, Palmeiral IP, Rodrigues ILA, Ferreira AMR, Ozela CS. O impacto do diagnóstico da tuberculose mediante suas representações sociais. Rev Bras Enferm. 2019;72(5):1254-61. doi: 10.1590/0034-7167-2017-0881

3. Viana PVS, Redner P, Ramos JP. Fatores associados ao abandono e ao óbito de casos de tuberculose drogarresistente (TBDR) atendidos em um centro de referência no Rio de Janeiro, Brasil. Cad Saúde Pública. 2018;34(5):e00048217. doi: 10.1590/0102-311X00048217

4. World Health Organization. Global Tuberculosis Report 2019 [Internet]. Geneva: World Health Organization, 2019 [cited 2018 Jul 15]. Available from: https://apps.who.int/iris/bitstream/handle/10665/329368/9789241565714-eng.pdf

5. World Health Organization. Global Tuberculosis Report 2018 [Internet]. Geneva: World Health Organization, 2018 [cited 2018 Jul 15]. Available from: https://apps.who.int/iris/bitstream/handle/10665/274453/9789241565646-eng.pdf

6. Ministério da Saúde (BR), Secretaria de Vigilância em Saúde, Boletim Epidemiológico. Implantação do Plano Nacional pelo Fim da Tuberculose como Problema de Saúde Pública no Brasil: primeiros passos rumo ao alcance das metas [Internet]. Brasília: Ministério da Saúde (BR); 2018 [cited 2018 Oct 09];49. Available from: http://portalarquivos2.saude.gov.br/images/pdf/2018/marco/26/2018-009.pdf

7. Brunello MEF, Orfão NH, Andrade RLP, Magnabosco GT, Arakawa T, Monroe AA, et al. Tuberculose: análise do percurso do doente durante o tratamento em Ribeirão Preto/SP. Rev Eletr Enf. 2016;18:e1176. doi: 18. 10.5216/ree.v18.39051

8. Orlandi GM, Pereira EG, Biagolini REM, França FOS, Bertolozzi MR. Incentivos sociais na adesão ao tratamento da tuberculose. Rev Bras Enferm. 2019;72(5):1247-53. doi: 10.1590/0034-7167-2017-0654

9. Basta PC, Marques M, Oliveira RL, Cunha EAT, Resendes APC, Souza-Santos R. Social inequalities and tuberculosis: an analysis by race/color in Mato Grosso do Sul, Brazil. Rev Saúde Pública. 2013;47(5):854-64. doi: 10.1590/S0034-8910.2013047004628

10. Lima SS, Vallinoto ACR, Machado LFA, Ishak MOG, Ishak R. Spatial analysis of tuberculosis in Belém, Pará State, Brazil. Rev Pan-Amaz Saúde. 2017;8(2):57-65. doi: 10.5123/s2176-62232017000200007

11. Queiroz AAR, Berra TZ, Garcia MCC, Popolin MP, Belchior AS, Yamamura M, et al. Padrão espacial e tendência temporal da mortalidade por tuberculose. Rev Latino-Am Enfermagem. 2018;26:e2992. doi: 10.1590/1518-8345.2049.2992

12. Ibiapina E, Bernardes A. O mapa da saúde e o regime de visibilidade contemporâneo. 2019;28(1):322-336. doi: 10.1590/ S0104-12902019170982

13. Ministério da Saúde (BR), Secretaria de Políticas de Saúde, Departamento de Atenção Básica. Manual técnico para o controle da tuberculose: cadernos de atenção básica [Internet]. Brasília: Ministério da Saúde (BR); 2002 [cited 2019 Aug 9]. Available from: http://bvsms.saude.gov.br/ bvs/publicacoes/manual_tecnico_controle_tuberculose_cab6.pdf

14. Ferreira DP, Souza FBA, Motta MCS. Abandono de tratamento anterior e caso de tuberculose multidroga resistente em uma instituição terciária na cidade do Rio de Janeiro. Rev Pesqui: Cuid Fundam. 2019;11(4):962-7. doi: 10.9789/2175-5361.2019.v11i4.962-967

15. Peruhype RC, Mitano F, Hoffmann JF, Surniche CA, Palha PF. Vias do planejamento na transferência do tratamento diretamente observado da tuberculose. Rev Latino-Am Enfermagem. 2018;26:e3015. doi: 10.1590/1518-8345.2213.3015

16. Pereira AGL, Escosteguy CC, Gonçalves GB, Marques MRVE, Brasil CM, Silva MCS. Factores asociados com la muerte y el abandono del tratamiento de la tuberculosis en un hospital general del municipio de Río de Janeiro, 2007 a 2014. Rev Epidemiol Control Infec. 2018;8(2):150-8. doi: 10.17058/reci.v8i2.10675

17. Santos JN, Sales CMM, Prado TN, Maciel EL. Factors associated with cure when treating tuberculosis in the state of Rio de Janeiro, Brazil, 2011-2014. Epidemiol Serv Saude. 2018;27(3):e2017464. doi: 10.5123/s1679-49742018000300015

18. Ferreira ALS, Nogueira LMV, Sá AMM, Ozela CS. Costs of the search for tuberculosis diagnosis: impact on the family economy. Rev Cuid. 2018;9(3):2400-12. doi: 10.15649/cuidarte.v9i3.536 
19. Afshar B, Carless J, Roche A, Balasegaram S, Anderson C. Surveillance of tuberculosis (TB) cases attributable to relapse or reinfection in London, 2002-2015. PLoS ONE. 2019;14(2):e0211972. doi: 10.1371/journal.pone.0211972

20. Rodrigues MW, Melo AGNC. Tuberculosis and schooling: a literature review. Rev Int Apoyo Inclus, Logopedia, Soc Multicult [Internet]. 2018 [cited 2018 aug 04];4(2):1-12. Available from: https://revistaselectronicas.ujaen.es/index.php/riai/article/download/4314/3539/

21. Fregona G, Cosme LB, Moreira CMM, Bussular JL, Dettoni VV, Dalcolmo MP, Zandonade E, et al. Risk factors associated with multidrugresistant tuberculosis in Espírito Santo, Brazil. Rev Saude Pública. 2017;51(41). doi: 10.1590/S1518-8787.2017051006688

22. Peruhype RC, Sicsú AN, Lima MCRAD, Hoffmann JF, Palha PF. Transferência de política: perspectiva do tratamento diretamente observado da tuberculose. Texto Contexto Enferm. 2018;27(3):e1710017. doi: 10.1590/0104-070720180001710017

23. Jacobs MG, Pinto Jr VL. Brazilian cities profile, the occurrence of tuberculosis and its drug-resistant form. Ciênc Saúde Colet. 2019;24(7). doi: 10.1590/1413-81232018247.20532017

24. Neves RR, Ferro OS, Nogueira LMV, Rodrigues ILA. Acess and link to treatement of tuberculosis in primary health care. Rev Pesqui: Cuid Fundam. 2016;8(4):5143-9. doi: 10.9789/2175-5361.2016.v8i4.5143-5149

25. Mullerpattan JB, Udwadia ZZ, Banka RA, Ganatra SR, Udwadia ZF. Catastrophic costs of treating drug resistant TB patients in a tertiary care hospital in India. Indian J Tuberculosis [Internet]. 2019 [cited 2019 May 04];66:87-91. Available from: http://tbresearch.ntiindia.org.in/id/ eprint/2476

26. Alene KA, Adane AA, Yifiru S, Bitew BD, Adane A, Koye DN. Knowledge and practice of health workers about control and prevention of multidrug-resistant tuberculosis in referral hospitals, Ethiopia: a cross-sectional study. BMJ Open. 2019;9:e022948. doi: 10.1136/ bmjopen-2018-022948

27. Oliveira RCC, Sá LD, Dias DCB, Pinheiro PGOD, Palha PF, Nogueira JA. Speeches of managers about the policy of the directly observed treatment for tuberculosis. Rev Bras Enferm. 2015;68(6):761-8. doi: 10.1590/0034-7167.2015680611i

28. Sousa LO, Mitano F, Lima MCRAA, Sicsú AN, Silva LMC, Palha PF. Short-course therapy for tuberculosis: a discourse analysis. Rev Bras Enferm. 2016;69(6):1089-98. doi: 10.1590/0034-7167-2016-0330

29. Valença MS, Possuelo LG, Cesar-Vaz MR, Silva PEA. Tuberculose em presídios brasileiros: uma revisão integrativa de literatura. Ciên Saúde Coletiva. 2016;21(7):2147-60. doi: 10.1590/1413-81232015217.16172015

30. San Pedro A, Gibson G, Santos JPC, Toledo LM, Sabroza PC, Oliveira RM. Tuberculose como marcador de iniquidades em um contexto de transformação socioespacial. Rev saúdepública [Internet]. 2017 [cited 2018 aug 04];51(7):51-59. Available from: http://dx.doi.org/10.1590/ s1518-8787.2017051006533

31. Pereira AGL, Escosteguy CC, Valencia LIO, Magalhões MAFM, Medronho RA. Spatial distribution and socioeconomic context of tuberculosis in Rio de Janeiro, Brazil, Brasil. Rev Saúde Pública. 2015;49:48. doi: 10.1590/S0034-8910.2015049005470

32. Silva MC, Pimentel MAS. Indicadores socioambientais do distrito administrativo de Icoaraci (Daico) Belém - Pará. Rev Contribuc Cien Soc [Internet]. 2018 [cited 2019 Sep 15]. Available from: http://www.eumed.net/rev/cccss/2018/01/indicadores-socioambientais.html

33. Fusco APB, Arcêncio RA, Yamamura M, Palha PF, Reis AA, Alecrim TFA, et al. Distribuição espacial da tuberculose em um município do interior paulista, 2008-2013. Rev Latino-Am Enfermagem. 2017;25:e2888. doi: 10.1590/1518-8345.1064.2888

34. Prado JJC, Virgilio TC, Medronho RA. Cure rates for tuberculosis in the municipality of Rio de Janeiro, Brazil, in 2012 compared with coverage by, and time of establishment of, Family Health units, and socio-economic and demographic factors. Ciên Saúde Coletiva. 2016;21(5):14918. doi: 10.1590/1413-81232015215.03912016

35. Oliveira U, Brescovit AD, Santos AJ. Delimiting Areas of Endemism through Kernel Interpolation. Plos One. 2015;10(1):e0116673. doi: 10.1371/journal.pone.0116673

36. Instituto Brasileiro de Geografia e Estatística (IBGE). Anuário Estatístico do Município de Belém 2011 [Internet]. 2011. Brasil: IBGE; 2011 [cited 2018 Nov 08]. Available from: http://www.belem.pa.gov.br/app/ANUARIO_2011/2_01_Demografia.pdf 